\title{
Analysis of the micronization process effect on the amino acid composition in compound feed
}

\author{
Dmitry Rudoy ${ }^{1}$, Victor Pakhomov ${ }^{1,2}$, Tatyana Maltseva ${ }^{1, *}$, Natalia Kulikova ${ }^{1}$, Natia \\ Ugrekhelidze $^{1}$, Larisa Enalyeva $^{1}$, and Arkady Babajanyan ${ }^{1}$ \\ ${ }^{1}$ Don State Technical University, 344003, Gagarin sq., 1, Rostov-on-Don, Russia \\ ${ }^{2}$ State Scientific Establishment "Agricultural Research Center "Donskoy", 347740, 14, Lenin st., \\ Zernograd, Russia
}

\begin{abstract}
The article presents the results of a study of the effect of feed samples micronization on proteinogenic amino acids, such as: arginine, lysine, tyrosine, phenylalanine, histidine, leucine-isoleucine, methionine, valine, proline, tyrosine, serine, alanine. The optimal parameters of the micronization process of compound feed have been substantiated in order to increase the digestibility of feed and disinfection.
\end{abstract}

\section{Introduction}

Feeding has a decisive influence on the growth, development, health and productivity of farm animals, birds and fish. Therefore, the main task in the conduct of intensive livestock, poultry, fish farming - is to improve nutrient utilization at the lowest cost per unit of production. The completeness of feeding depends on the balance of rations, which must satisfy the needs of animals for nutrients, minerals, vitamins, etc. The lack of certain elements leads to an increased consumption of compound feed.

To increase the digestibility of feed, various methods of exposure are used: grinding, hydrothermal treatment (steaming, extrusion, etc.), micronization.

The micronization process is one of the methods of heat treatment of compound feed and raw materials for its production. "Mikronizing", L.T.D. (England) was the first to implement this process on an industrial scale for processing feed grains in order to increase its nutritional value. Heat treatment of compound feed and raw materials for its production allows solving important problems in compound feed production: to increase the nutritional value and digestibility of compound feed due to the breakdown of indigestible substances; to improve organoleptic quality indicators; ensure microbiological safety due to disinfection; reduce the strength characteristics of lumpy grain, which will reduce energy consumption for its grinding and further processing into compound feed products [1-7].

Compared to the granulation process, which increases the digestibility of compound feed by only $4.5 \%$, the process of micronization of compound feed increases its digestibility up to $20 \%$.

The essence of the micronization process of fodder grain and compound feed is as follows: during micronization, grain or compound feed is exposed to intense irradiation of

\footnotetext{
* Corresponding author: vif.tatyana@yandex.ru
} 
the incident flow of infrared (IR) rays with a wavelength of 1.7 to $3.4 \mu \mathrm{m}$ for $40-180 \mathrm{~s}$. Penetrating into the material, infrared rays heat up the absorbent substances, causing highfrequency (80 to 170 million megacycles per second) vibration in its molecules. As a result, the processed material instantly heats up from the inside, the moisture that is part of the grain and feed evaporates, and due to the high heating rate, the pressure of water vapor rises sharply, which leads to the acceleration of chemical and biological processes [7-15].

The processing time and heating power have a significant impact on the components of grain and feed. When overheated, starch becomes poorly assimilated, denaturation of proteins occurs, destruction of proteinogenic amino acids, which reduces the nutritional value of feed grains and feed and reduces their quality [2-3, 9-10].

\section{Materials and methods}

For the experiment, three samples of extruded compound feed were taken. In the composition of which were present: fish meal (sample № 1), meat and bone meal (sample № 2), mussels (sample №3). Also, all samples contained such components as cake, meal, feed wheat. Each sample was processed under different modes, which are presented in Table 1. The processing time was constant $-60 \mathrm{~s}$.

Table 1. Micranization parameters for compound feed processing

\begin{tabular}{|l|c|c|c|}
\hline \multicolumn{1}{|c|}{ Parameters } & Mode 1 & Mode 2 & Mode 3 \\
\hline Input power, $\mathrm{W}$ & 1280 & 1100 & 1280 \\
\hline Output power, $\mathrm{W}$ & 450 & 700 & 800 \\
\hline Frequency, $\mathrm{Hz}$ & 50 & 50 & 50 \\
\hline Temperature, ${ }^{\circ} \mathrm{C}$ & 60 & 90 & 95 \\
\hline
\end{tabular}

The method for determining the amino acid composition of compound feeds by capillary electrophoresis makes it possible to determine the total content of amino acids in the samples (total free and bound forms). Since asparagine and glutamine are quantitatively hydrolyzed to aspartic and glutamic acids, respectively, during the decomposition of samples, the data on the content of aspartic and glutamic acids represent the total content of these acids and the corresponding amides. Under the conditions of measurements, leucine and isoleucine are not separated, therefore, their total determination is provided.

The method is based on the decomposition of samples by acid hydrolysis with the conversion of amino acids into free forms, preparation of phenylthiohydantoin derivatives, their further separation and quantitative determination by capillary electrophoresis. Detection is carried out in the ultraviolet region of the spectrum at a wavelength of $254 \mathrm{~nm}$.

Arginine, lysine, tyrosine, phenylalanine, histidine, the sum of leucine and isoleucine, methionine, valine, proline, threonine, serine, alanine and glycine are determined in the test samples after acid hydrolysis.

Electrophoretic separation is performed using phosphate buffered saline under the conditions of the analysis.[18-20]

For the analysis, three samples of compound feed were taken, differing in the recipe: sample № 1 - protein component: fish meal; sample № 2 - protein component: meat and bone meal; sample № 3 - protein component: mussels. All studied samples of compound feed were processed in a micraniser using three modes: power $450 \mathrm{~W}, 700 \mathrm{~W}$ and $800 \mathrm{~W}$. All samples were crushed to pass through a $1.0 \mathrm{~mm}$ sieve. 


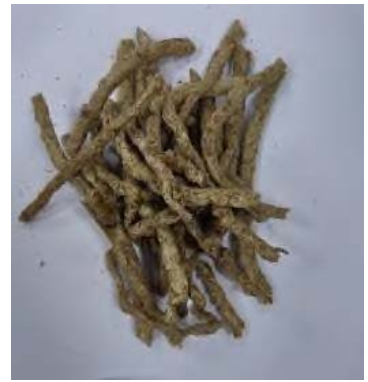

Sample 1

With fish meal

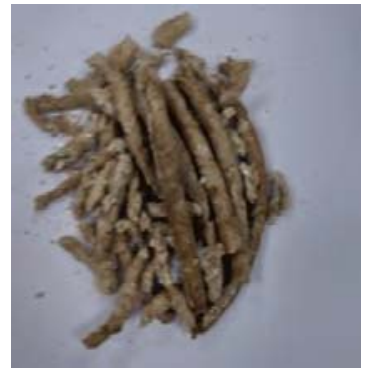

Sample 2

With meat and bone meal

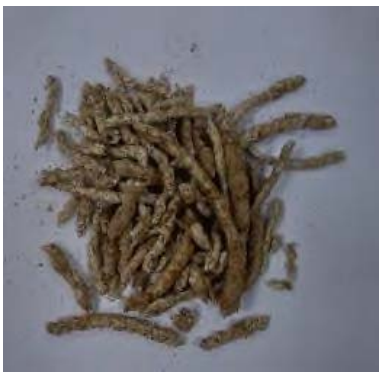

Sample 3

With mussels

Fig. 1. Samples of the studied compound feed.

There were prepared all the solutions necessary for research, namely:

sodium hydroxide solution for capillary flushing;

solution of hydrochloric acid with a molar concentration of $1 \mathrm{~mol} / \mathrm{dm} 3$ for hydrolysis according to scheme 1 and 2;

phosphate buffer solution - leading electrolyte for 1 and 2 schemes;

sodium carbonate solution of molar concentration $0.1 \mathrm{~mol} / \mathrm{dm} 3$ for the preparation of phenylthiohydantoin derivatives;

phenyl isothiocyanate solution (PITC) for the preparation of phenylthiohydantoin derivatives;

oxidizing mixture for hydrolysis according to scheme 2 ;

mixtures of amino acids for system calibration.

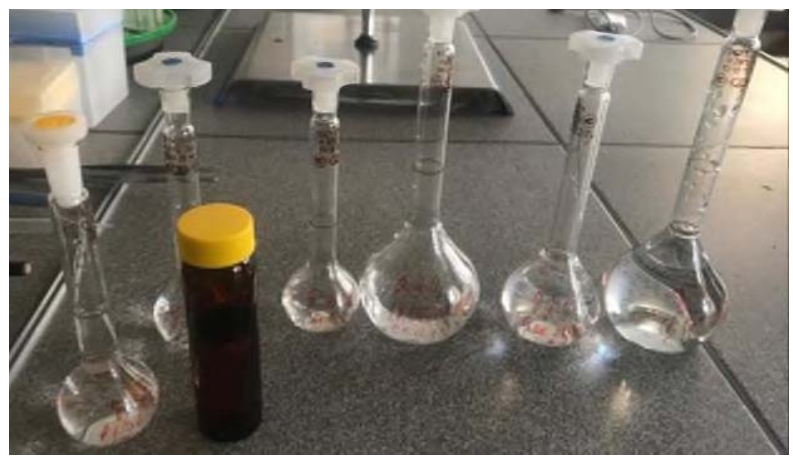

Fig. 2. Analysis solutions

Hydrolysis of samples. To determine the amino acid composition of the compound feed, the analyzed sample weighing $(0.100 \pm 0.001) \mathrm{g}$ is placed in a vial for hydrolysis, $10.0 \mathrm{ml}$ of hydrochloric acid is added. The hydrolysis vial is sealed with a screw cap and mixed.[1618]

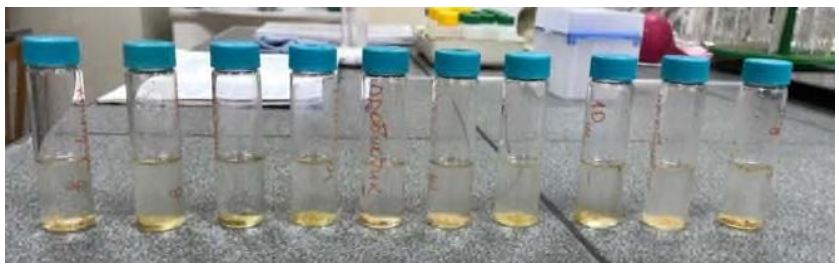

Fig. 3. Analyzed samples before hydrolysis 
The hydrolysis vials are placed in an oven. The hydrolysis is carried out at a temperature of $110^{\circ} \mathrm{C}$ for $14-16$ hours.

At the end of the hydrolysis, the vials for determining the basic composition of amino acids are removed from the cabinet and cooled to room temperature. Figure 3 shows samples after hydrolysis.

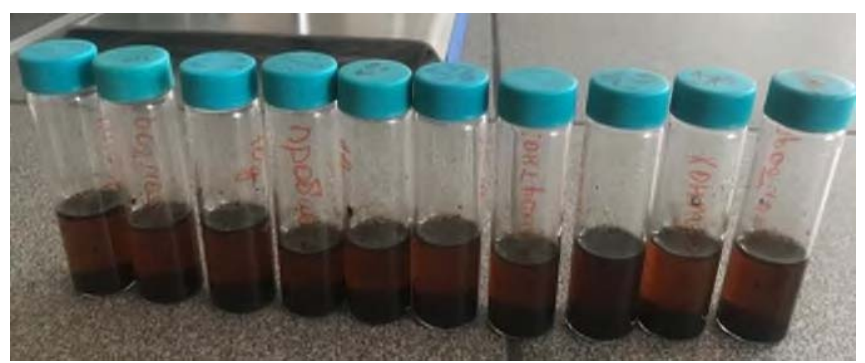

Fig. 4. Analyzed samples after hydrolysis

After cooling, the contents of the hydrolysis vial are filtered through "blue ribbon" filters, discarding the first portions and collecting the filtrates in a container with lids to avoid evaporation.

After filtration, the samples are transferred to phenylthiohydantoin derivatives. Samples after filtration are shown in the figure 5 .

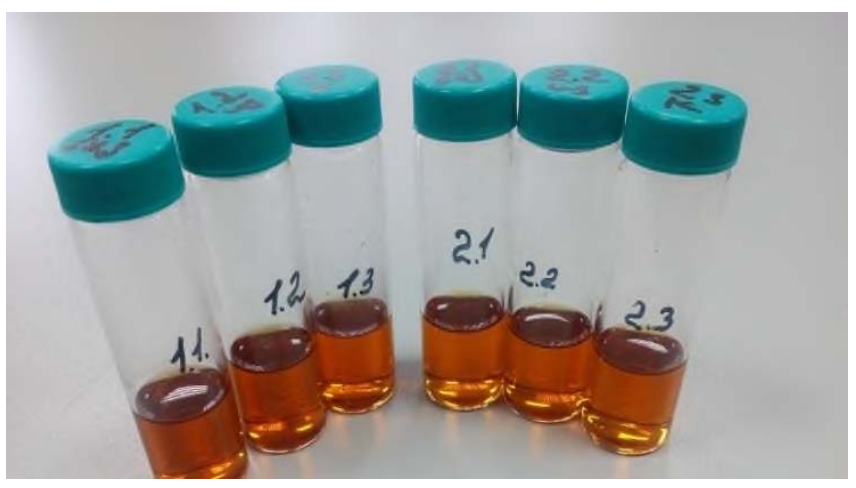

Fig. 5. Hydrolyzate of analyzed samples after filtration

In glass bottles with a capacity of $10-15 \mathrm{ml}, 0.05 \mathrm{ml}$ of prepared hydrolysates are taken. The solutions are evaporated to dryness in a stream of warm air. $0.15 \mathrm{ml}$ of sodium carbonate solution and $0.3 \mathrm{ml}$ of phenyl isothiocyanate solution (PITC) are added to each bottle with dry residues. Stir thoroughly until the precipitate dissolves, close the lid and leave for $35 \mathrm{~min}$ at room temperature. Then the solutions are evaporated to dryness in a stream of warm air.

The dry residues are dissolved in $0.5 \mathrm{ml}$ of distilled water.

The measurements were carried out on a Kapel 104T capillary electrophoresis system. The prepared solutions were transferred into Eppendorf tubes, centrifuged for $5 \mathrm{~min}$ at a rotation speed of $5000 \mathrm{rpm}[4-5,12]$.

For each prepared solution, at least two electrophoregrams are recorded. As a result of the analysis, electrophoregrams were obtained for each sample (Figure 5-8). 


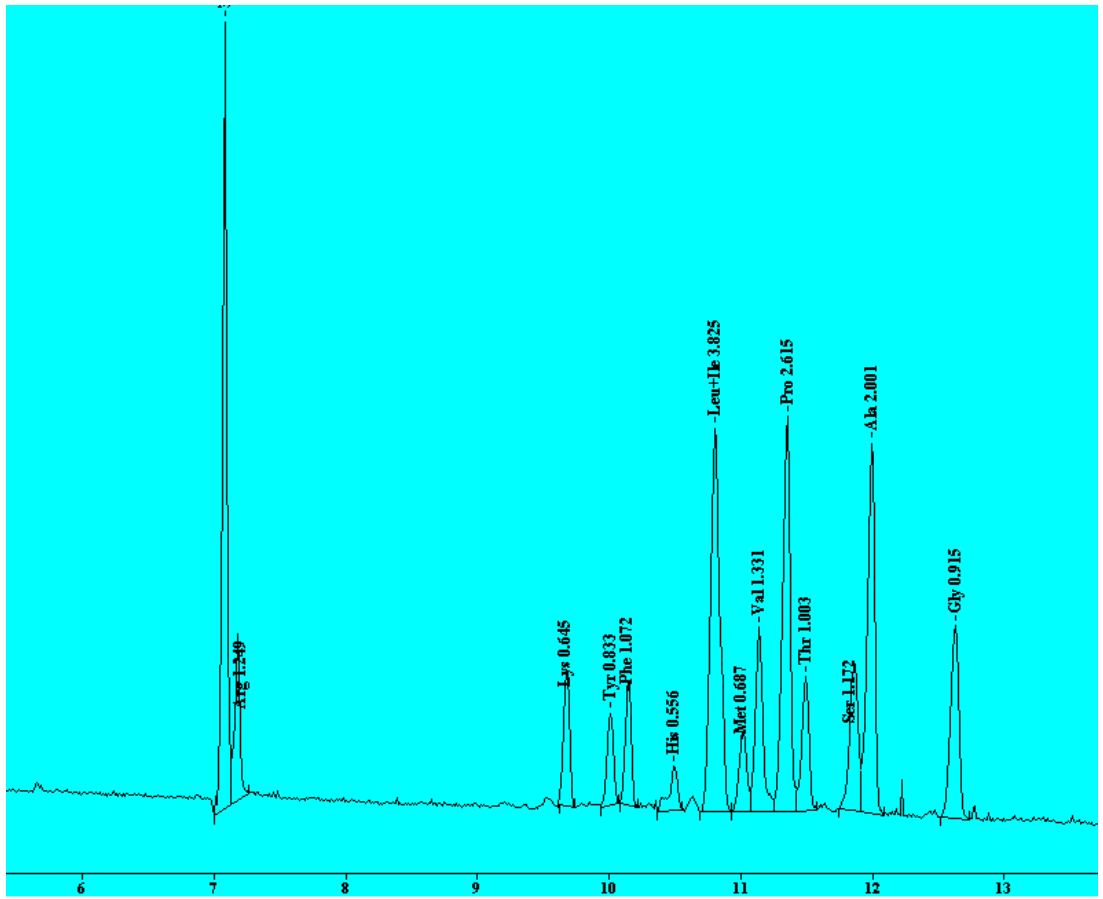

Fig. 6. Electropherogram for determination of basic amino acids in sample № 1 (with fish meal) before processing

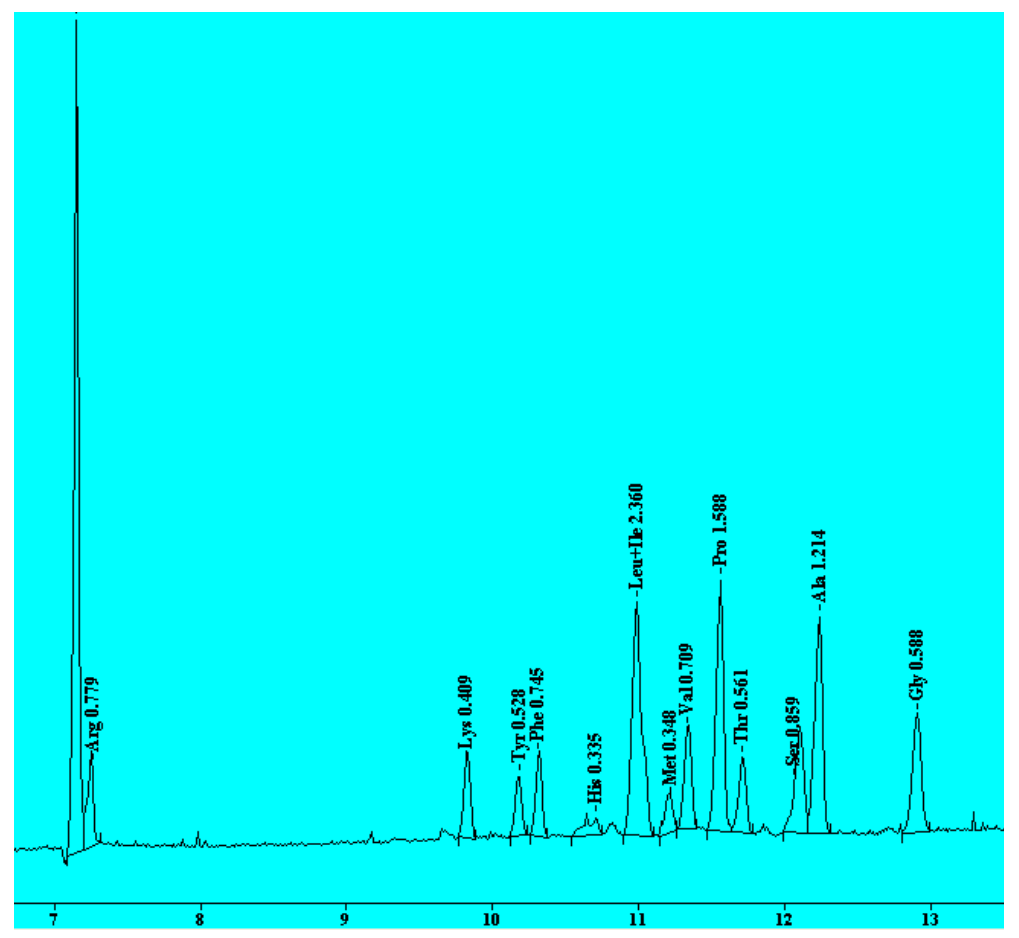

Fig. 7. Electropherogram for determination of basic amino acids in sample № 2 (with meat and bone meal) before processing 


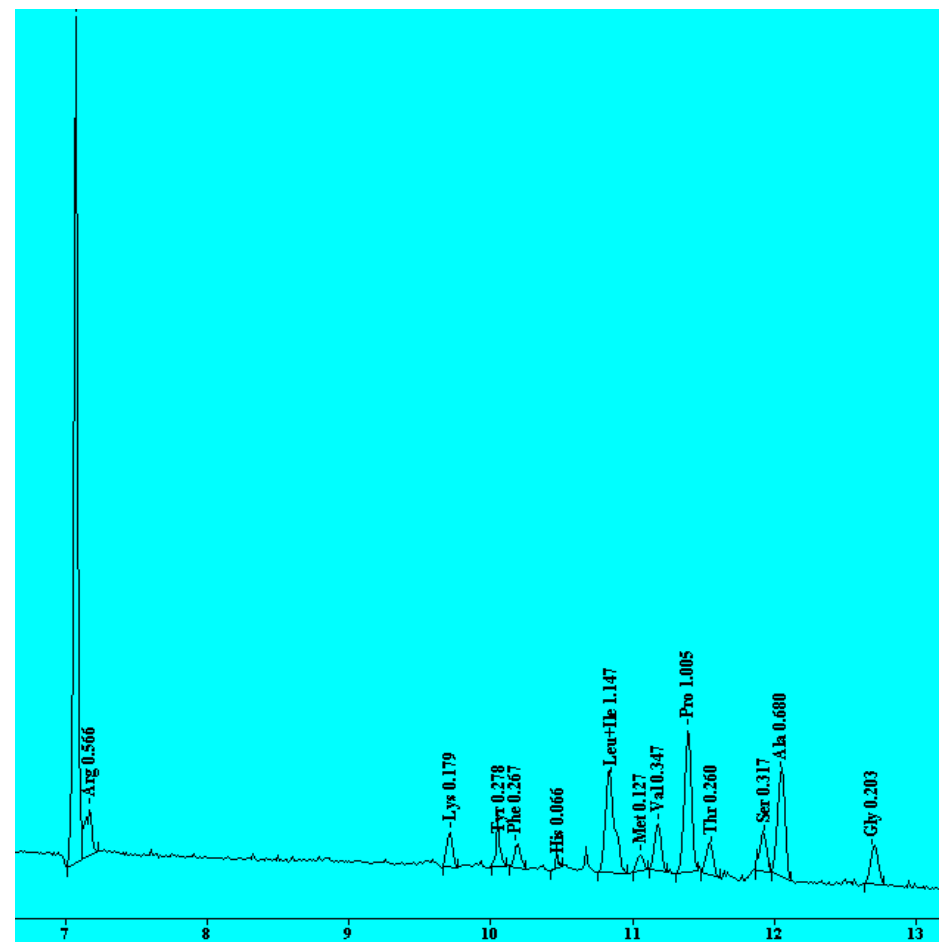

Fig. 8. Electropherogram for the determination of basic amino acids in sample № 3 (with mussels) before treatment

After detecting amino acids and marking peaks, the mass concentration of each amino acid was determined.

The mass fraction of each amino acid in sample X,\%, was calculated by the formula:

$$
X=\frac{C_{i} \cdot 10}{m}
$$

where $C_{i}$ - measured value of mass concentration of amino acid in solution, $\mathrm{mg} / \mathrm{l}$;

$\mathrm{m}$ - mass of the analyzed sample, $\mathrm{mg}(100 \mathrm{mg})$;

10 - conversion factor.

The results obtained were processed using the Statistica program and are presented in tables $2-4$.

\section{Results and conclusions}

In all studied samples, an increase in the mass fraction of the analyzed amino acids is observed several times. This is due to the properties of amino acids: when exposed to heat, they bind to various substances and the resulting compounds are not cleaved by enzymes in the stomach, but hydrolyzed by acids when they are quantitatively determined; high temperatures increase the availability and assimilation of amino acids for animals. Also, there is a decrease in the number of amino acids by $10-15 \%$ (namely: proline, methionine, histidine and tyrosine) after ultrahigh frequency processing at $800 \mathrm{~W}$ compared to samples processed at 450 and $700 \mathrm{~W}$ in all analyzed samples. Tables $2-4$ show the results of determining the amino acid composition in three samples [13]. 
Table 2. Change in amino acids in the sample № 1 (with fish meal)

\begin{tabular}{|c|c|c|c|c|}
\hline Amino acid & $\begin{array}{c}\text { Sample before } \\
\text { processing }\end{array}$ & $\mathbf{4 5 0} \mathbf{~ w}$ & $\mathbf{7 0 0} \mathbf{~}$ & $\mathbf{8 0 0} \mathbf{~ w}$ \\
\hline Arg & 0.020 & 0.036 & 0.020 & 0.059 \\
\hline Lys & 0.012 & 0.018 & 0.020 & 0.020 \\
\hline Tyr & 0.021 & 0.023 & 0.033 & 0.019 \\
\hline Phe & 0.021 & 0.042 & 0.048 & 0.047 \\
\hline His & 0.018 & 0.021 & 0.018 & 0.013 \\
\hline Leu-Ile & 0.049 & 0.096 & 0.112 & 0.103 \\
\hline Met & 0.011 & 0.016 & 0.026 & 0.006 \\
\hline Val & 0.012 & 0.043 & 0,051 & 0.042 \\
\hline Pro & 0.096 & 0.126 & 0.153 & 0.012 \\
\hline Thr & 0.015 & 0.028 & 0.031 & 0.032 \\
\hline Ser & 0.026 & 0.052 & 0.058 & 0.056 \\
\hline Ala & 0.020 & 0.039 & 0.041 & 0.044 \\
\hline
\end{tabular}

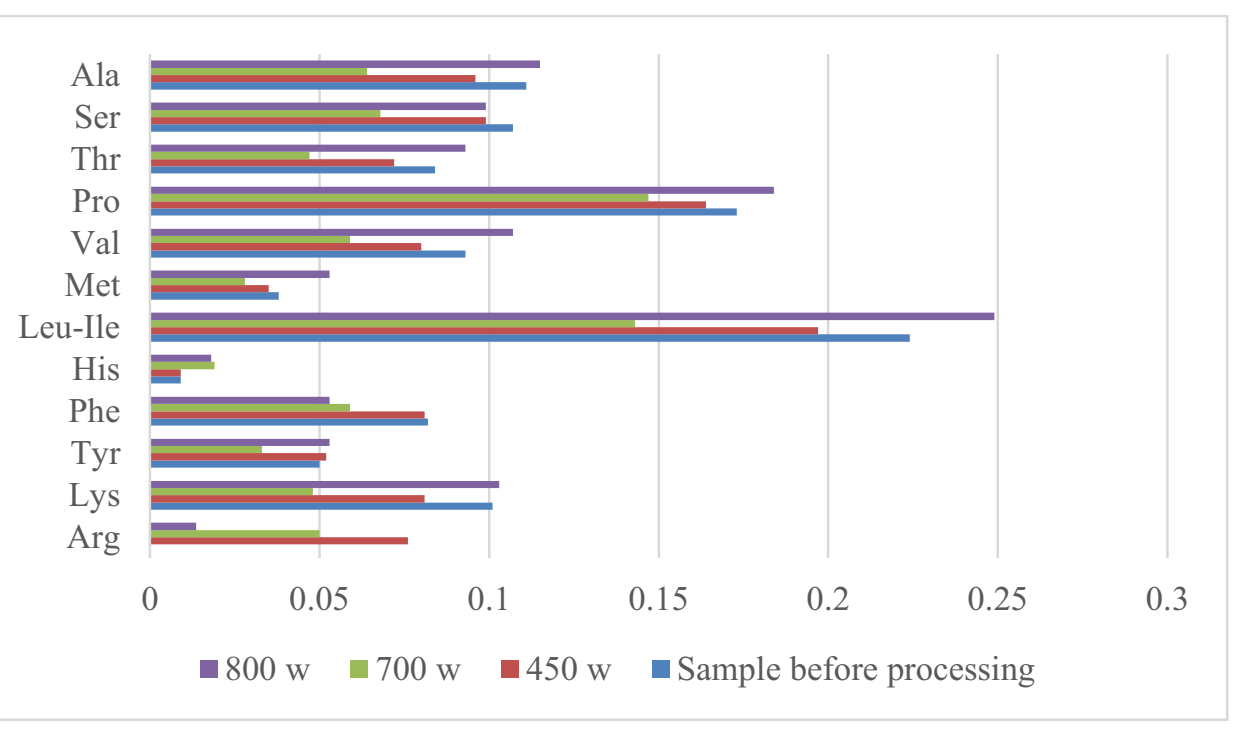

Fig. 6. Diagram of changes in amino acids in the sample 1

Table 3. Change in amino acids in the sample 2 (with meat and bone meal)

\begin{tabular}{|c|c|c|c|c|}
\hline Amino acid & $\begin{array}{c}\text { Sample before } \\
\text { processing }\end{array}$ & $\mathbf{4 5 0} \mathbf{~ w}$ & $\mathbf{7 0 0} \mathbf{~ w}$ & $\mathbf{8 0 0} \mathbf{~}$ \\
\hline Arg & 0.029 & 0.091 & 0.144 & 0.058 \\
\hline Lys & 0.012 & 0.028 & 0.030 & 0.022 \\
\hline Tyr & 0.017 & 0.020 & 0.024 & 0.024 \\
\hline Phe & 0.023 & 0.047 & 0.053 & 0.024 \\
\hline His & 0.009 & 0.012 & 0.014 & 0.056 \\
\hline Leu-Ile & 0.055 & 0.108 & 0.123 & 0.018 \\
\hline Met & 0.014 & 0.021 & 0.021 & 0.119 \\
\hline Val & 0.013 & 0.048 & 0.048 & 0.024 \\
\hline Pro & 0.100 & 0.120 & 0.138 & 0.056 \\
\hline Thr & 0.018 & 0.035 & 0.038 & 0.143 \\
\hline Ser & 0.031 & 0.061 & 0.066 & 0.036 \\
\hline
\end{tabular}




\begin{tabular}{|c|c|c|c|c|}
\hline Ala & 0.021 & 0.046 & 0.048 & 0.047 \\
\hline
\end{tabular}

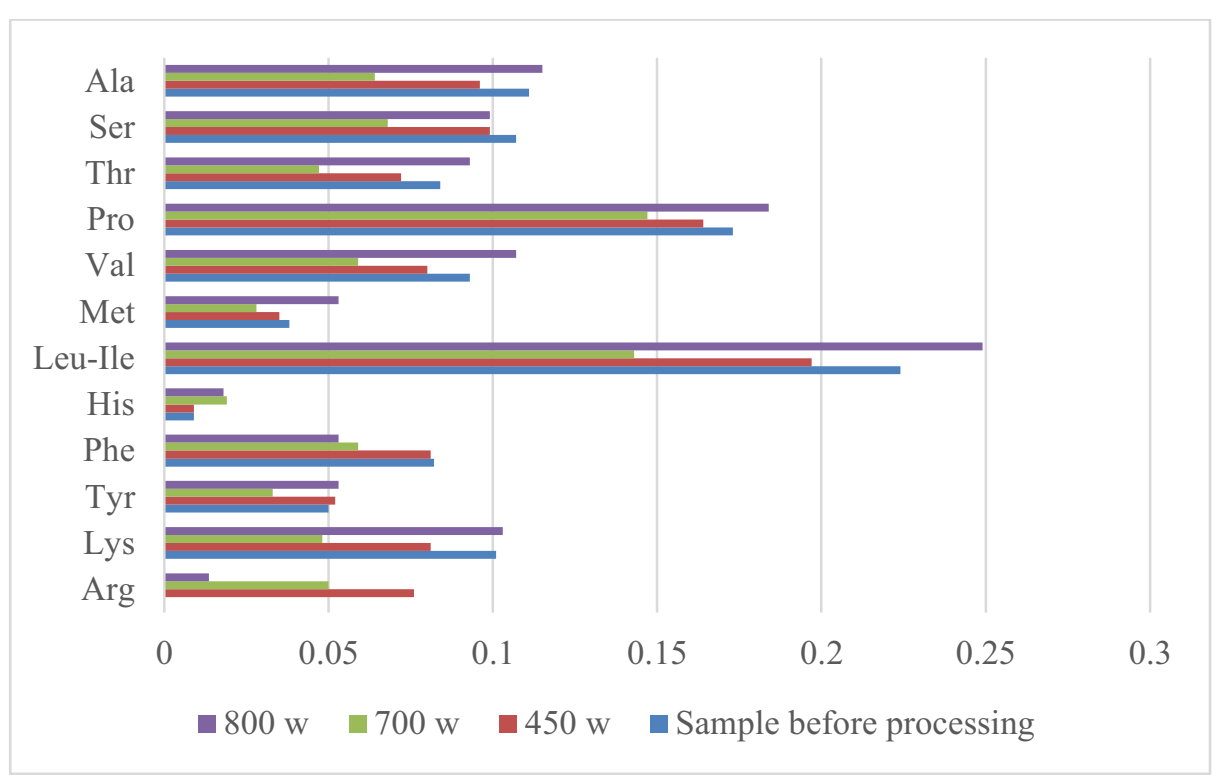

Fig.6. Diagram of changes in amino acids in the sample 2.

Table 4. Change in amino acids in the sample 3.

\begin{tabular}{|c|c|c|c|c|}
\hline Amino acid & $\begin{array}{c}\text { Sample before } \\
\text { processing }\end{array}$ & $\mathbf{4 5 0} \mathbf{w}$ & $\mathbf{7 0 0} \mathbf{~ w}$ & $\mathbf{8 0 0} \mathbf{~ w}$ \\
\hline Arg & 0.088 & 0.076 & 0.050 & 0.0136 \\
\hline Lys & 0.101 & 0.081 & 0.048 & 0.103 \\
\hline Tyr & 0.050 & 0.052 & 0.033 & 0.053 \\
\hline Phe & 0.082 & 0.081 & 0.059 & 0.053 \\
\hline His & 0.009 & 0.009 & 0.019 & 0.018 \\
\hline Leu-Ile & 0.224 & 0.197 & 0.143 & 0.249 \\
\hline Met & 0.038 & 0.035 & 0.028 & 0.053 \\
\hline Val & 0.093 & 0.080 & 0.059 & 0.107 \\
\hline Pro & 0.173 & 0.164 & 0.147 & 0.184 \\
\hline Thr & 0.084 & 0.072 & 0.047 & 0.093 \\
\hline Ser & 0.107 & 0.099 & 0.068 & 0.099 \\
\hline Ala & 0.111 & 0.096 & 0.064 & 0.115 \\
\hline
\end{tabular}




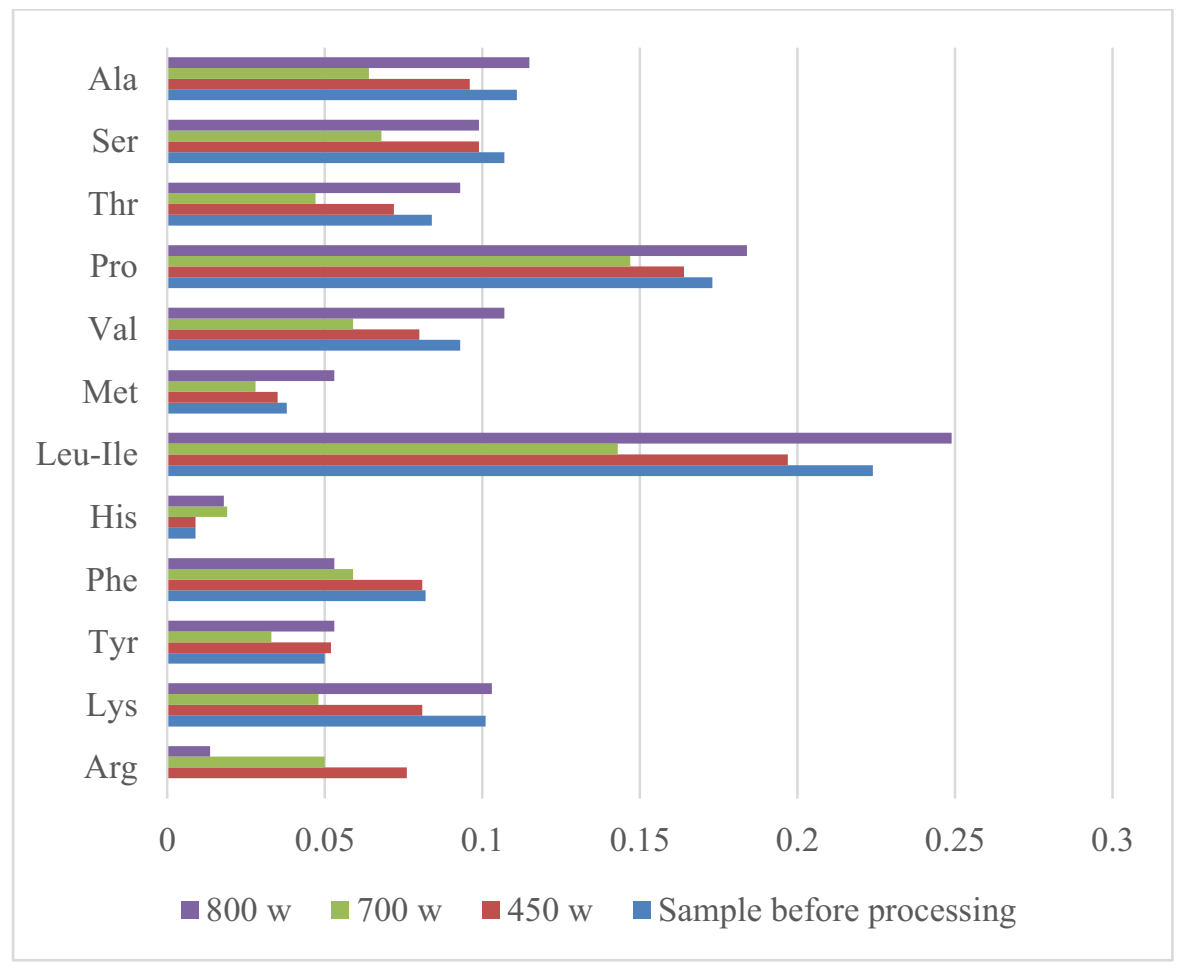

Fig.7. Diagram of changes in amino acids in the sample 3.

The research results have shown that the optimal parameters for micronization of feed pellets are $450-700 \mathrm{~W}$; processing time 60 seconds. With these parameters, the quantitative amino acid composition of the compound feed is preserved, and the highest availability and assimilation of amino acids for animals is observed. Taking into account the results of research and the properties of amino acids under the influence of thermal, chemical and other factors, to pass into indigestible forms, the processing mode with a power of $800 \mathrm{~W}$ is unacceptable, since there is a significant decrease in amino acids (mostly proline, methionine, histidine and tyrosine) and their assimilability. [21]

Authors acknowledge the support of the Government of the Russian Federation (contract No. 075-152019-1880).

Also, the work was carried out as a groundwork for the president grant application № MK1700.2021 .5

\section{References}

1. V. Pakhomov, S. Braginets, O. Bakhchevnikov, D. Rudoy, Effect of extrusion on nutritional composition of feed containing mussel meat: Experimental study results, Engineering for Rural Development, 19, 306-312 (2020) doi: 10.22616/erdev.2020.19.tf073

2. E. Sokolova, V. Orobets, O. Sevostyanova, E. Gorchakov, D. Rudoy, A. Olshevskaya, A. Babajanyan, Toxicological evaluation of a new iron-containing preparation for farm animals with alimentary anemia, E3S Web of Conferences, 175, 03015 (2020) doi: $10.1051 /$ e3sconf/202017503015 
3. M. Mazanko, E. Prazdnova, D. Rudoy, A. Ermakov, A. Olshevskaya, T. Maltseva, Extracts of medical plants suppress the SOS response and reduce mutagenesis in E. coli E3S Web of Conferences, 175, 01010 (2020) doi: 10.1051/e3sconf/202017501010

4. A. Dhiman, P. K. Prabhakar, Journal of Food Engineering, 292, 110248 (2021) doi: 10.1016/j.jfoodeng.2020.110248

5. C. S. Speroni, A. B. B. Bender, J. Stiebe, C. A. Ballus, P. F. Ávilab, R. Goldbeck, F. Dal P. Morisso, L. P. da Silva, T. Emanuelli, LWT, 130, 109526 (2020) doi: 10.1016/j.lwt.2020.109526

6. J. C. López-Linares, M. T. García-Cubero, S. Lucas, G. González-Benito, M. Coca, Chemical Engineering Journal, 368, 1045-1055 (2019) doi: 10.1016/j.cej.2019.03.032

7. F. S. Stefanello, C. O. Santos, V. C. Bochi, A. P. B. Fruet, M. B. Soquetta, Andréa C. Dörr, J. L. Nörnberg, Food Chemistry, 239, 385-401 (2018) doi: 10.1016/j.foodchem.2017.06.130

8. W.-X. Peng, J. L. M. Marchal, A. F. B. van der Poe, Animal Feed Science and Technology, 237, 129-153 (2018) doi: 10.1016/j.anifeedsci.2018.01.017

9. M. Magnusson, C. R. K. Glasson, M. J. Vucko, A. Angell, T. L. Neoh, R. de Nys, A. Research, 41, 101555 (2019) doi: 10.1016/j.algal.2019.101555

10. M. M. El-Dalatony, S. Saha, S. P. Govindwar, R. A. I. Abou-Shanab, B.-H. Jeon, Trends in Biotechnology, 37(8), 855-869 (2019) doi: 10.1016/j.tibtech.2019.01.011

11. F. Dos Anjos, M. Vazquez-Anon, E. S. Dierenfeld, C. M. Parsons, M. Chimonyo, Journal of Applied Poultry Research, 25(1), 85-94 (2016) doi: 10.3382/japr/pfv069

12. N. Swanepoel, P. H. Robinson, Animal Feed Science and Technology, 258, 114318 (2019) doi: 10.1016/j.anifeedsci.2019.114318

13. M. A. Shah, K. Niaz, N. Aslam, C. Vargas-de la Cruz, A. Kabir, A. H. Khan, F. Khan, P. Panichayupakaranant, Recent Advances in Natural Products Analysis, 723-747 (2020) doi: 10.1016/B978-0-12-816455-6.00024-X

14. A. Cartus, Chemical Contaminants and Residues in Food (Second Edition), Woodhead Publishing Series in Food Science, Technology and Nutrition, 251-278 (2017) doi: 10.1016/B978-0-08-100674-0.00012-6

15. H. Harder, A. Khol-Parisini, B. U. Metzler-Zebeli, F. Klevenhusen, Q. Zebeli, Journal of Dairy Science, 98(11), 8107-8120 (2015) doi: 10.3168/jds.2015-9913

16. G. Parkhomenko, S. Kambulov, A. Olshevskaya, A. Babadzhanyan, N. Gucheva, I. Mekhantseva, IOP Conf. Series: Earth and Environmental Science, 403, 012144 (2019) IOP Publishing doi:10.1088/1755-1315/403/1/012144

17. A. Altybayev, A. Zhanbyrbayev, B. Meskhi, D. Rudoy, A. Olshevskaya, A. Prohorova, E3S Web of Conferences, 135, 01078 (2019) https://doi.org/10.1051/e3sconf/201913501078

18. I. Bozhko, G. Parkhomenko, S. Kambulov, A. Boyko, V. Kolodkin, M. Magomedov, D. Rudoy, E3S Web of Conferences 175, 05025 (2020) INTERAGROMASH 2020 https://doi.org/10.1051/e3sconf/202017505025

19. V. V. Ivanov, S. I. Popov, Ju. V. Marchenko, E. V. Marchenko, N. S. Dontsov, S. A. Timofeev, Thickness of vibrational mechanochemical solid-lubricant coating in friction pairs of transport engineering products. XII International Scientific Conference on Agricultural Machinery Industry (INTERAGROMASH 2019): IOP Conference Series: Earth and Environmental Science, 403, 012115 (2019) doi:10.1088/1755-1315/403/1/012115 
20. S. V. Teplyakova, A. A. Kotesova, S. I. Popov, A. A. Kotesov, The transition from the sample data to the total aggregate of the final volume and the analysis of this transition laws // International Scientific Conference "Construction and Architecture: Theory and Practice for the innovation Development» (CATPID-2020): IOP Conference Series: Materials Science and Engineering, 913, 042054 (2020) doi:10.1088/1757-899X/913/4/042054

21. A. A. Korotky, E. V. Marchenko, S. I. Popov, Ju. V. Marchenko, N. S. Dontsov, Theoretical foundations of modeling the process of transport vehicles steel ropes structural defects formation. XIII International Scientific and Practical Conference «State and Prospects for the Development of Agribusiness - INTERAGROMASH 2020»: E3S Web of Conferences, 175, $05018 \quad$ (2020) doi.org/10.1051/e3sconf/202017505018 